\title{
MORPHOMETRIC CHARACTERIZATION OF PART OF MURICIZAL RIVER WATERSHED - TOCANTINS, BRAZIL
}

\author{
Olavo da Costa Leite ${ }^{1}$, Saulo de Oliveira Lima ${ }^{2}$, Lawrence Nóbrega de Oliveira ${ }^{3}$, Rodrigo José da Silva ${ }^{4}$, \\ Gilson Araújo de Freitas ${ }^{5}$, Allan Deyvid Pereira da Silva ${ }^{6}$, Osvaldo José Ferreira Junior ${ }^{7}$
}

\begin{abstract}
:
The aim of this study is to carry out a superficial characterization on part of the watershed of River Muricizal, in Tocantins, from estimates based on climatic and morphometric parameters. The river basin in this study comprises an area from the monitoring station of River Muricizal, at Muricilândia pluviometric station in Tocantins state, code ANA 28150000 (- $7^{\circ} 08^{\prime} 43^{\prime \prime}$, and $-48^{\circ} 36^{\prime} 37^{\prime \prime}$, altitude 193m). The pluviometric stations were: code 748002, municipality of Nova Olinda- TO, 748003 municipality of Muricilândia - TO, and code 749000 municipality of Arapoema - TO. The basin under study covers the municipalities of Muricilândia - TO (11.0\%), Santa Fé do Araguaia - TO (6.0\%), Araguaína - TO (70.3\%) and Nova Olinda - TO (12.7\%). The watershed is divided into two sub - basins, comprising the total sub basin area of River Rio Preto (69.978.73 hectares) and part of the sub basin of River Muricizal (86,847.32 hectares), comprising a total drainage area of $1,568.26 \mathrm{~km}^{2}$. The analysis of the physiographic data is necessary, since it allows morphometric understanding about the area, such as land cover, land use, rainfall data, which is important to minimize impacts that can be caused.
\end{abstract}

Keywords: Hydrography, morphometry, watershed, mapping.

\section{CARACTERIZAÇÃO MORFOMÉTRICA DE PARTE DA BACIA HIDROGRÁFICA DO RIO MURICIZAL - TOCANTINS, BRASIL}

\section{RESUMO:}

O objetivo deste trabalho foi realizar uma caracterização superficial de parte da bacia hidrográfica do Rio Muricizal, Tocantins, a partir da estimativa de alguns parâmetros climáticos e morfométricos. A bacia compreende a área incremental a partir da estação de monitoramento localizada no rio Muricizal, município

\footnotetext{
${ }^{1}$ Geógrafo, Doutorando no Programa de Pós-Graduação em Produção Vegetal, Universidade Federal do Tocantins - UFT, Campus de Gurupi, Rua Badejós, Lote 7, Chácaras 69/72, Zona Rural, CEP: 77402-970, Gurupi (TO), Brasil. olavol@ hotmail.com.

${ }^{2}$ Engenheiro Agrônomo, Dsc. Professor da Universidade Federal do Tocantins, Departamento de Agronomia - Rua Badejós, Lote 7, Chácaras 69/72, Zona Rural. Caixa Postal 66. CEP: 77402-970 Campus de Gurupi (TO), Brasil. saulolima@uft.edu.br

${ }^{3}$ Engenheiro Florestal, Mcs. Analista Ambiental do Instituto Brasileiro do Meio Ambiente e dos Recursos Naturais Renováveis, Brasil, Campus de Gurupi, Rua Badejós, Lote 7, Chácaras 69/72, Zona Rural, CEP: 77402-970, Gurupi (TO), Brasil. eng.lawrencenobrega@gmail.com

${ }^{4}$ Engenheiro Agrônomo, Mcs. Professor do Instituto Federal do Tocantins - IFTO, Rua do Açude, Próximo ao Lago Municipal, CEP: 77470-000, - Centro, Formoso do Araguaia - TO, Brasil. rodrigo.silva@ifto.edu.br.

5 Pesquisador PNPD CAPES no Programa de Pós-Graduação em Produção Vegetal; Universidade Federal do Tocantins, Rua Badejós, Lote 7, Chácaras 69/72, Zona Rural. Caixa Postal 66. CEP: 77402-970, Campus de Gurupi (TO), Brasil. araujoagro@hotmail.com

${ }^{6}$ Geógrafo, Doutorando em Engenharia Florestal, Universidade Federal do Paraná, Curitiba, allanuft@ gmail.com

7 Engenheiro Agrônomo, Mestrando. Produção vegetal, Universidade Federal do Tocantins - UFT, Campus de Gurupi, Rua Badejós, Lote 7, Chácaras 69/72, Zona Rural, CEP: 77402-970, Gurupi (TO), Brasil. jr_uft@ hotmail.com (autor correspondente)
} 
de Muricilândia-TO, posto fluviométrico Muricilândia - código ANA 28150000 (- 708'43' ' e - 48³6'37', altitude 193m). Os postos pluviométricos utilizados foram: código 748002, município de Nova Olinda-TO, código 748003, município de Muricilândia - TO e código 749000, município de Arapoema-TO. A bacia em estudo abrange os municípios de Muricilândia-TO (11,0\%), Santa Fé do Araguaia-TO (6,0\%), AraguaínaTO $(70,3 \%)$ e Nova Olinda-TO (12,7\%). A bacia está dividida em duas sub-bacias, compreendendo a área total da sub-bacia do Rio Preto (69.978,73 hectares) e parte da sub-bacia do Rio Muricizal (86.847,32 hectares), correspondendo a uma área total de drenagem de $1.568,26 \mathrm{~km}^{2}$. A análise dos dados fisiográficos é necessária, pois permite conhecimento morfométrico da área, como cobertura da terra, potencialidade do uso da terra, dados pluviométricos, sendo estes fundamentais para minimizar prováveis impactos.

Palavras-Chave: Hidrografia, morfometria, bacia hidrográfica, mapeamento. 


\section{INTRODUCTION}

The watershed of Muricizal River has its territorial extension mostly in the municipality of Araguaína- Tocantins, one of the largest cities in the region, second only to the Capital Palmas. In this municipality, there is a concentration of national and multinational companies in the agribusiness sector, which also include the export of beef. In addition to the agro-industry the city of Araguaína also stands out in the commerce and specialized services.

According to Tundisi (2013), watershed unit needs a management system for territorial planning of hydro-resources. This is fundamental for the creation of a set of action plans and activities aimed at the development of projects guided at integrated hydro-resources management. In other words, a management plan that emphasizes the functional and operational systemic dimension related to strategic planning (Tundisi, 2013).

Silva (2016), also points out that the surface runoff of a river watershed is highly relevant to the understanding of adequate watershed management indicators. Especially, when the runoff is caused by precipitation intensity, soil infiltration capacity, and vegetation coverage of the land. After all, this runoff is responsible for the formation of hydrological elements of the watershed (Silva, 2016). In this context, Merten et al. (2011) describe a watershed by three different elements: the basin, the riparian environment, which in many cases is non-existent, and the river channel that drains the water flow and the sediments produced at the basin.

The delimitation of a watershed based in geographic information systems is an automated management of topographic maps. It presents databases in different cost-effective environments minimizing conflicts in water resources managements units.

For Tomazoni et al. (2011), the use of a digital elevation model generated by SRTM (Shuttle Radar Topography Mission) and other databases make it possible to characterize the drainage network, in order to obtain the image representation of relief vegetation of the riparian forests and it also describes the true situation of the location.

According to Viola et al (2009), the evaluation of the impacts on water resources produced by different agricultural land use is one of the most relevant applications of hydrological models. It is also fundamental for the environmental planning of watersheds (Viola et al., 2009).

In Alvarenga's view, the mapping model using geostatistical techniques, must take into consideration the analysis of the watershed characteristics. It must also be based on the crossvalidation and prediction, in order to generate better quality distribution at the mapping database (Alvarenga et al. 2011).

Vanzela and Franco (2010) have also discussed the use and occupation of the soils, noting that the native vegetation coverage has greater capacity for soil water storage infiltration. This causes, reduction of runoff to the water source bed, increasing specific flow and the improvement in water quality, compared to: a) inhabited areas, b) farmed areas and c) altered degraded forests, that reduced the specific flow and water quality of the Sub-basin in general.

Considering the above, the objective of this work was to characterize part of the watershed of the Muricizal River, in Tocantins, based on the estimate from some climatic and morphometric parameters.

\section{MATERIAL AND METHODS}

The watershed of River Muricizal, in this study, is situated in the north region of Tocantins. It occupies an area of $3,375.6 \mathrm{~km}^{2}$ (SEPLAN, 2012). The area is divided in two basins: the area of River Preto sub-basin $(69,978.73)$ and part of Muricizal sub-basin (86,847.32 hectares) including a total surface runoff area of $1,568.26 \mathrm{~km}$. The whole watershed is a tributary of River Araguaia (Figure $1)$.

The climate was classified according to Thornthwaite, as B1wA ' $a$ ', humid with moderate hydro-deficiency in winter time with 
evapotranspiration potential, presenting an average annual variation between 1,400 and 1,700 mm; and around 390 and $480 \mathrm{~mm}$ distributed in the summer over three consecutive months of the highest temperature (SEPLAN, 2012).

The watershed is located in the municipalities of Muricilândia-TO (11.0\%), Santa Fé do Araguaia-TO (6.0\%), Araguaína-TO (70.3\%) and Nova Olinda TO, (12.7\%). It has low urban activity, since it has no municipal headquarters around. According to IBGE (2018), the estimated population sum of these municipalities is 198.594 inhabitants (IBGE, 2018).

The river basin studied here comprises an area from the monitoring station of River Muricizal, at Muricilândia pluviometric station in Tocantins state - code ANA 28150000 (- 708'43' and 48'36'37', altitude $193 \mathrm{~m})$. The pluviometric stations were: code 748002 (- $7^{\circ} 33^{\prime} 38^{\prime \prime}$ and $48^{\circ} 25^{\prime} 22^{\prime}$ ', altitude $\left.257 \mathrm{~m}\right), 748003\left(-7^{\circ} 09^{\prime} 16^{\prime \prime}\right.$ ' and - 48 36'11', altitude $393 \mathrm{~m})$ and 749000 (-
7'39'19' ' and - 48 03'54', altitude $215 \mathrm{~m}$ ) and its respective influential areas (Figure 2), were determined by means of the Thiessen polygons method, whose method is widely used for the interpolation of rainfall data.

According to Marciano et al. (2018), there are several methods to calculate the mean rainfall precipitation rate, such as: the arithmetic mean method, isohyet method and Thiessen method. The former is the most used; the arithmetic mean method is very simplistic as it does not take into account the distribution of rainfall stations and the relief. The isohyet method, on the contrary, is more complex, as it requires more precise information on rainfall precipitation of the studied areas. Thiessen's method, on the other hand, consists of using an area of the basin and the stations location, tracing the polygons and the ridge lines of the relief. As a result, it generates a digital model of elevation, turning the proposed method more difficult to display topography information on non-rugged terrain.

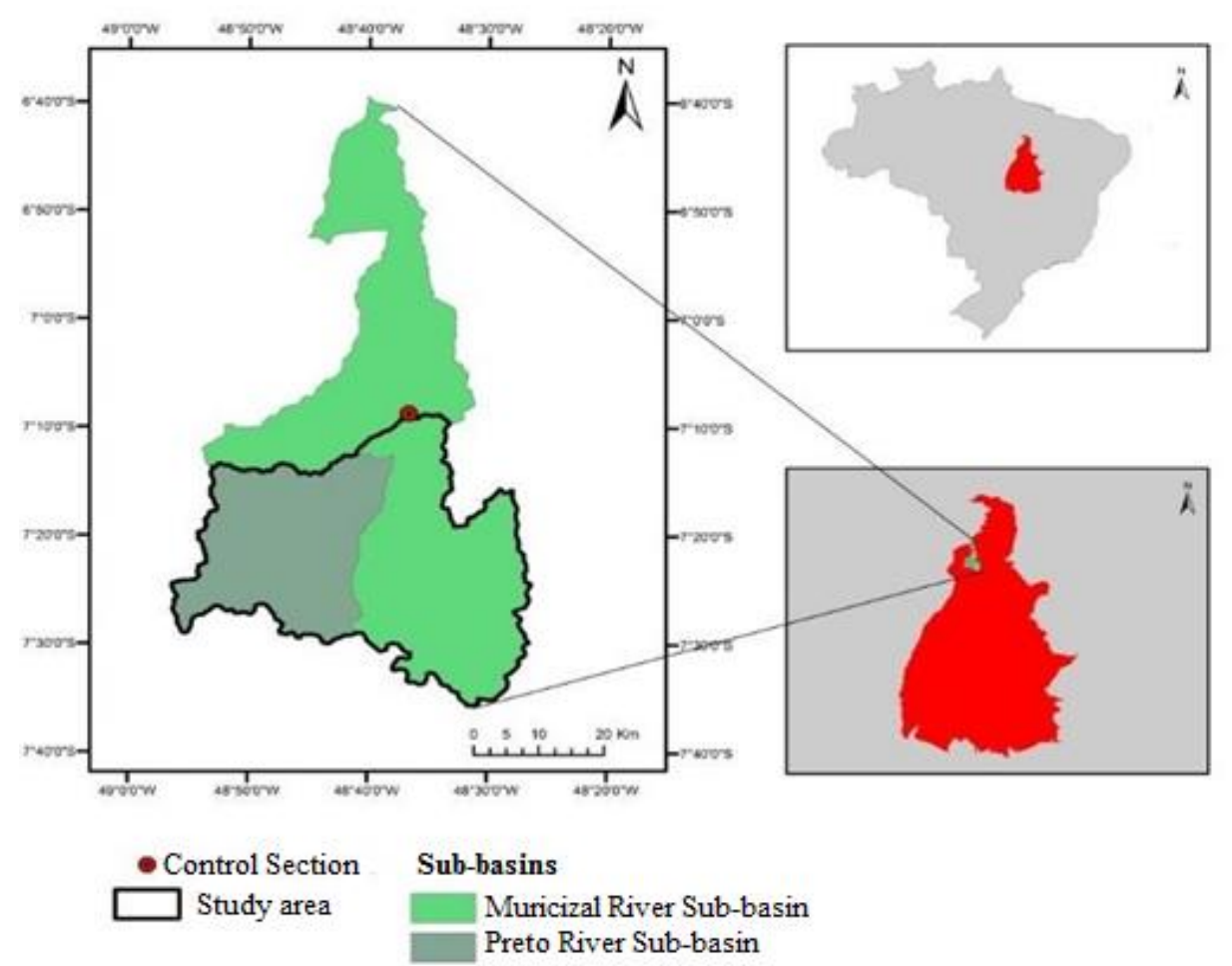

Figure 1. Hydrographic region of Muricizal River, highlighting the sub-basins. Source: (Adapted from, 2012) 


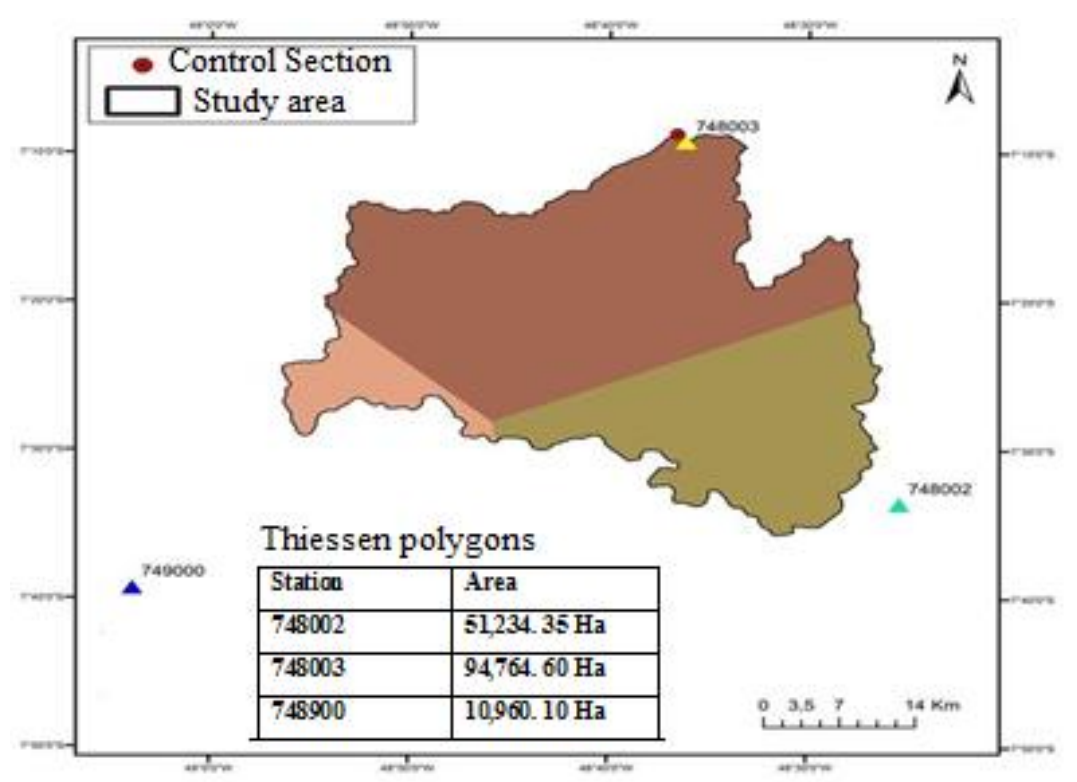

Figure 2. Control section and pluviometric data stations of the Muricizal sub-basin. Source: (adapted from Tocantins, 2012)

The compactness coefficient $(\mathrm{Kc})$ calculates the correlation between the river basin perimeter and the circumference of a circle, that is, the farthest to the unit, the lower the possibility of flooding (Villela and Matos, 1975).

The Kc was obtained using the following equation:

$$
K c=\frac{0.28 \times P}{\sqrt{A}}
$$

Where: $\mathrm{Kc}=$ compactness coefficient $\mathrm{P}=$ Perimeter $(\mathrm{m})$ and $\mathrm{A}=$ Area.

The Circularity Index (Ic) is similar to the compactness coefficient, and leans towards the unity as the basin follows a circular shape. The following equation was used:

$$
I c=\frac{4 \pi x A}{P^{2}}
$$

(Equation 02)

Where: $\mathrm{Ic}=$ circularity index, $\mathrm{A}=$ drainage area $\left(\mathrm{m}^{2}\right)$ and $\mathrm{P}=$ perimeter $(\mathrm{m})$.

Drainage Density is defined by the average length of rivers with the watershed per unit area. Drainage density (Dd) was obtained by using the following equation:

$$
D d=\frac{\sum L t}{A}
$$

(Equation 03)

Where: $\mathrm{Dd}=$ drainage density $\left(\mathrm{km} \cdot \mathrm{km}^{-2}\right), \mathrm{Lt}$ $=$ total length of all channels $(\mathrm{km})$ and $\mathrm{A}=$ drainage area $\left(\mathrm{km}^{2}\right)$.

Sinuosity is the relationship between the distance from the mouth of the river and the farthest straight line distance of the river source, and the length of the main river in vector format. The sinuosity index of the main watercourse was calculated by using the following equation:

$$
S i=\frac{L}{L t}
$$

(Equation 04)

Where: $\mathrm{Lt}=$ Total length of straight line and $\mathrm{L}=$ Length of the man river in vector format.

The annual water balance equation is described by:

Addition $=$ decrease $+\mathrm{D}$ (soil moisture storage)

The water balance analysis takes into account the annual water storage cycles in the soil, where in average annual terms there is a balance, so that the final evaluation of the water balance can be done according to the simplified equation: 


$$
E T=P-Q
$$

\section{(Equation 05)}

Where: $\mathrm{ET}=$ evapotranspiration $(\mathrm{mm}), \mathrm{P}=$ precipitation $(\mathrm{mm})$ and $\mathrm{Q}=$ Discharge $(\mathrm{mm})$

The following maps were elaborated in GIS environment: 1) land use potentiality; 2) pedology; 3) relief; and 4) vegetation. Software such as ArcGIS 10.0, datum and SIRGAS2000 were used in the maps preparation, along with the Landsat8 satellite images, OLI sensor, RGB band 764 composition. The areas were calculated in the Albers conical projection, using a vector database from the Planning and modernization Office of Public management in Tocantins State.

\section{RESULTS AND DISCUSSION}

The results showed that there was less precipitation in $1976(1,409 \mathrm{~mm})$, than in 2005 $(2,051 \mathrm{~mm})$ with an average series of $1709 \mathrm{~mm}$ (Table 1).This data corresponds to the historical series registered by the Hydrological System of Information from the National Water Agency (ANA, 2018) using the Thiessen polygon method. The relative amounts of rain based on rainfall behaviour analysis at regional scales are important to show the rainfall distribution at each location of the watershed.

The results show that the rainfall distribution of the Muricizal river basin presents annual variations rates compared to the three rainfall stations (table 1). Thus, variation in rainfall within the same watershed is evident. Undoubtedly if there were a larger number of stations, the rainfall control would be obtained with greater precision.

According to Viola et al. (2014), the state of Tocantins presents distinct rainfall concentration, with greater precipitation from the north areas of Bananal Island to the south region of "Bico do Papagaio". It is possible that these characteristics are related to the climatic influence exerted by the Amazon.
As Marcuzzo and Goularte (2012) points out, Tocantins state has a humid tropical climate, with great variation at the interannual rainfall index with differences in precipitation each month. This conclusion was reached in a study on quantification of pluviometric data, based on Tocantins rainfall anomaly index. In addition, it was observed a significant decrease in rainfall in the state of Tocantins during the studied historical period from 1977 to 2006.

According to the study the periods from October to April are responsible for approximately $90.16 \%$ of all annual precipitation of the state. This is due to the continental equatorial air mass present during this time of the year.

Data analysis of the historical series from Muricilândia pluviometric station (Table 1), identified that the lowest annual average flow occurred in $1998\left(19.6 \mathrm{~m}^{3} / \mathrm{s}\right)$, the highest in 1989 $\left(44.3 \mathrm{~m}^{3} / \mathrm{s}\right)$ where the series average was $30.8 \mathrm{~m}^{3} / \mathrm{s}$. The water balance analysis in the historical series 1976 - 2005 shows that evapotranspiration was higher than the discharge in most of the period evaluated, except for 1991 when evapotranspiration corresponded to $63.8 \%$ of rainfall (Figure 3 ).

According to Cardoso et al. (2006), runoff is the difference between rainwater that flows over the land and the evaporative losses. Therefore, when comparing two basins that have the same precipitation values, there are varying amount of runoff, since they will have different physical characteristics such as solar radiation, soil type, wind, vegetation, among others.

Sari et al (2016) report that canopy rainfall interception can affect hydrological behavior due to the energy absorption of the raindrop as it falls (increasing water infiltration into the soil).This is because evapotranspiration encompasses all processes involved in transforming water from the earth's surface to steam. As a consequence, it can also influence on hydrological modelling processes. 
Table 1. Temporal Series of Pluviometric data per base station by the Thiessen method, and the flow rate for Muricilândia station in Tocantins state.

\begin{tabular}{|c|c|c|c|c|c|}
\hline \multirow{2}{*}{ Year } & \multicolumn{3}{|c|}{ Average annual precipitation $(\mathrm{mm})$ by Weather Station } & \multirow{2}{*}{$\begin{array}{c}\text { Thiessen P } \\
(\mathbf{m m})\end{array}$} & \multirow{2}{*}{$\begin{array}{c}\text { Muricilândia } Q \\
\left(\mathrm{~m}^{3} / \mathrm{s}\right)\end{array}$} \\
\hline & 748.002 & 748.003 & 749.000 & & \\
\hline 1976 & 1,633 & 1,232 & 1,881 & 1,409 & 19.7 \\
\hline 1977 & 1,700 & 1,331 & 1,975 & 1,498 & 26.5 \\
\hline 1978 & 1,631 & 1,331 & 1,934 & 1,472 & 29.7 \\
\hline 1979 & 2,096 & 1,360 & 2,322 & 1,669 & 29.9 \\
\hline 1980 & 1,800 & 1,358 & 1,842 & 1,537 & 28.7 \\
\hline 1981 & 1,723 & 1,468 & 1,699 & 1,569 & 23.1 \\
\hline 1982 & 1,932 & 1,324 & 1,775 & 1,555 & 26.0 \\
\hline 1983 & 1,738 & 1,380 & 1,546 & 1,510 & 25.4 \\
\hline 1984 & 1,747 & 1,703 & 1,370 & 1,696 & 26.7 \\
\hline 1988 & 1,949 & 1,595 & 1,802 & 1,727 & 30.6 \\
\hline 1989 & 2,170 & 1,961 & 2,016 & 2,035 & 44.3 \\
\hline 1990 & 2,010 & 1,553 & 1,427 & 1,695 & 29.2 \\
\hline 1991 & 1,428 & 1,448 & 1,667 & 1,458 & 39.7 \\
\hline 1993 & 2,103 & 1,670 & 2,006 & 1,836 & 21.5 \\
\hline 1994 & 2,027 & 1,953 & 2,086 & 1,988 & 31.8 \\
\hline 1995 & 1,646 & 1,995 & 2,098 & 1,890 & 39.6 \\
\hline 1996 & 1,807 & 1,848 & 1,603 & 1,819 & 39.5 \\
\hline 1997 & 1,384 & 1,978 & 2,345 & 1,811 & 39.1 \\
\hline 1998 & 1,287 & 1,418 & 2,029 & 1,419 & 19.6 \\
\hline 1999 & 1,342 & 2,064 & 1,967 & 1,823 & 31.5 \\
\hline 2000 & 1,400 & 1,917 & 1,945 & 1,751 & 41.9 \\
\hline 2001 & 1,749 & 1,841 & 1,879 & 1,815 & 28.8 \\
\hline 2002 & 1,594 & 1,945 & 1,812 & 1,823 & 30.2 \\
\hline 2003 & 1,468 & 1,753 & 1,766 & 1,662 & 27.1 \\
\hline 2004 & 1,733 & 2,035 & 1,855 & 1,926 & 34.8 \\
\hline 2005 & 1,926 & 2,101 & 2,179 & 2,051 & 34.9 \\
\hline Average & - & - & - & 1709 & 30.8 \\
\hline
\end{tabular}

$\mathrm{P}=$ Annual precipitation measured by the Thiessen polygon method; $\mathrm{Q}=$ annual average flow rate for Muricilândia pluviometric station. 


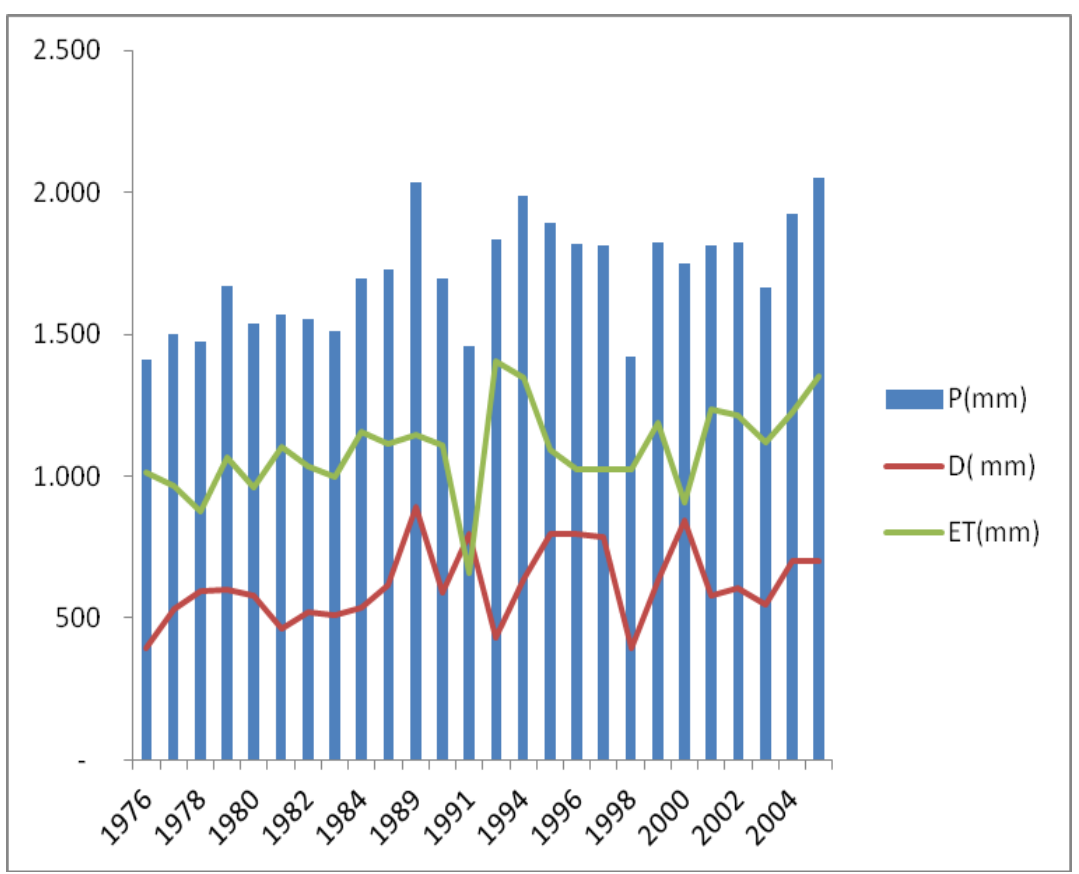

Figure 3. The figure shows the relationship between precipitation (P), Discharge (D) and evapotranspiration (ET) over the studied period. Source: (Adapted from ANA, 2018)

Based on the historical series described above, this process of precipitation and evapotranspiration and watershed runoff causes oscillation in the flow of the watercourse in different months of the year. Therefore, changing the water balance based on the historical series described above.

The morphometric characterization of the Muricizal river basin revealed that the length of the main river is $105.84 \mathrm{~km}$ and the total of the channels basin is $2,344.61 \mathrm{~km}$. The drainage density of $1.5 \mathrm{~km}$ $\mathrm{Km}^{-2}$ (Table 2) is considered low according to Lolo (1995). In addition, the watershed circularity index (Ic) was 0.35 (Table 2), which characterizes it as an elongated basin with lower flooding risk.

The mapping of land use potential showed that most of the basin area is recommended for crops of short and long life-cycles, as well as intensive livestock (Figure 4). Parameters related to natural conservation were also attributed to a smaller range of soil; however, the management history of these areas has been used for pastures with little or no technological input, which may result in the use of non-recommended crops with low yield.
In view of this, it is important to emphasize that land use management can be put into practice, when divisions of land use potential is recognized and acknowledged, as an effective instrument for conducting environmental studies. In this sense, mapping the area for the evaluated products is of high relevance for balanced decision making, especially in regards to the availability of natural resources with viable environmental projects, either by public or private initiative.

Rampim et al. (2012) state that the use of land without proper planning causes impoverishment and low crop yields, resulting in a decrease in the socioeconomic and technological status, of the rural population. Hence, previous diagnosis of land use potential contributes to the understanding of the environment adaptability for various purposes. Mainly to maximise its use and to avoid soil degradation or depletion, since its use indicates the degree of cultivation intensity which can be applied in any field avoiding decrease in yield. Positively, it results in maximum land use without risk of degradation (Lepsch et al., 1991). 
In this sense, the planning of soil conservation practices must take into account individual characteristics of each watershed, so that better results with environmental management can be achieved (LEPSCH et al., 1991; RAMPIM et al., 2012)The watershed pedological mapping showed that the territory is composed of Acrisols (76.5\%), Quartzarenic Neosols (18.5\%) and Oxisols (lathosols) (5\%) (Figure 5).

The Acrisols are composed of mineral material which includes clay with high or low activity. Andit presents a textural diagnostic horizon B, coupled with low base saturation in most of this horizon; Neosols are poorly evolved soils without any type of horizon $\mathrm{B}$; and the Oxisols are soils made of mineral material, with lathosolic (oxisol) horizon B, below horizon A, within 200 to $300 \mathrm{~cm}$ of the soil surface (EMBRAPA, 2013).There has been a few studies detailing the pedological mapping either though quantitative, or qualitative analyses, or through other means of characterization .Thus, the result described above shows that the basin does not have diversification of soil types, and may come from the relief types found in the area.

Oliveira (2014) points out that relief has an important role as a soil formation factor, it influences greatly on soil exposure time and in its respective types. Thus, there is a need for the implementation of management practices for soil coverage and conservation in order to reduce the degradation promoted by incorrect conservation and use. Therefore, a few things can be suggested such as: animal management, soil correction with forage species, among others.

Erodibility represents how susceptible the soil particles are to being detached and transported by the action of an erosive agent. In this view, and from the characteristics, properties and composition of the soil, it is possible to infer its natural susceptibility to erosion (Panachuki et al, 2006, Demarchi e Zimback, 2014).

Four erodibility classes were identified at Muricizal river basin: mild (35.7\%), moderate $(13.9 \%)$, strong $(23.4 \%)$ and very strong (27.0\%) (Figure 5) The accelerated soil erosion is caused by surface erosion due to the mechanical and chemical action of running water, weather or other geological agents (Mello et al., 2012).

Table 2. Morphometric Parameters of Muricizal River basin.

\begin{tabular}{ccc}
\hline Physical Characteristics & Units & Results \\
\hline Drainage area & $\mathrm{Km}^{2}$ & $1,568.26$ \\
Perímeter & $\mathrm{Km}$ & 236.787 \\
Length of the main river & $\mathrm{Km}$ & 105.84 \\
Total length of all channels & $\mathrm{Km}$ & $2,344.61$ \\
Compactness Coefficient (Kc) & -- & 1.67 \\
$\quad$ Circularity index (Ic) & - & 5.29 \\
Sinuosity index of the main watercourse $(\mathrm{Si})$ & & \\
$\quad$ Basin order & $(\mathrm{m})$ & 618 \\
Maximum Altitude & $(\mathrm{m})$ & 160 \\
Minimum Altitude & &
\end{tabular}




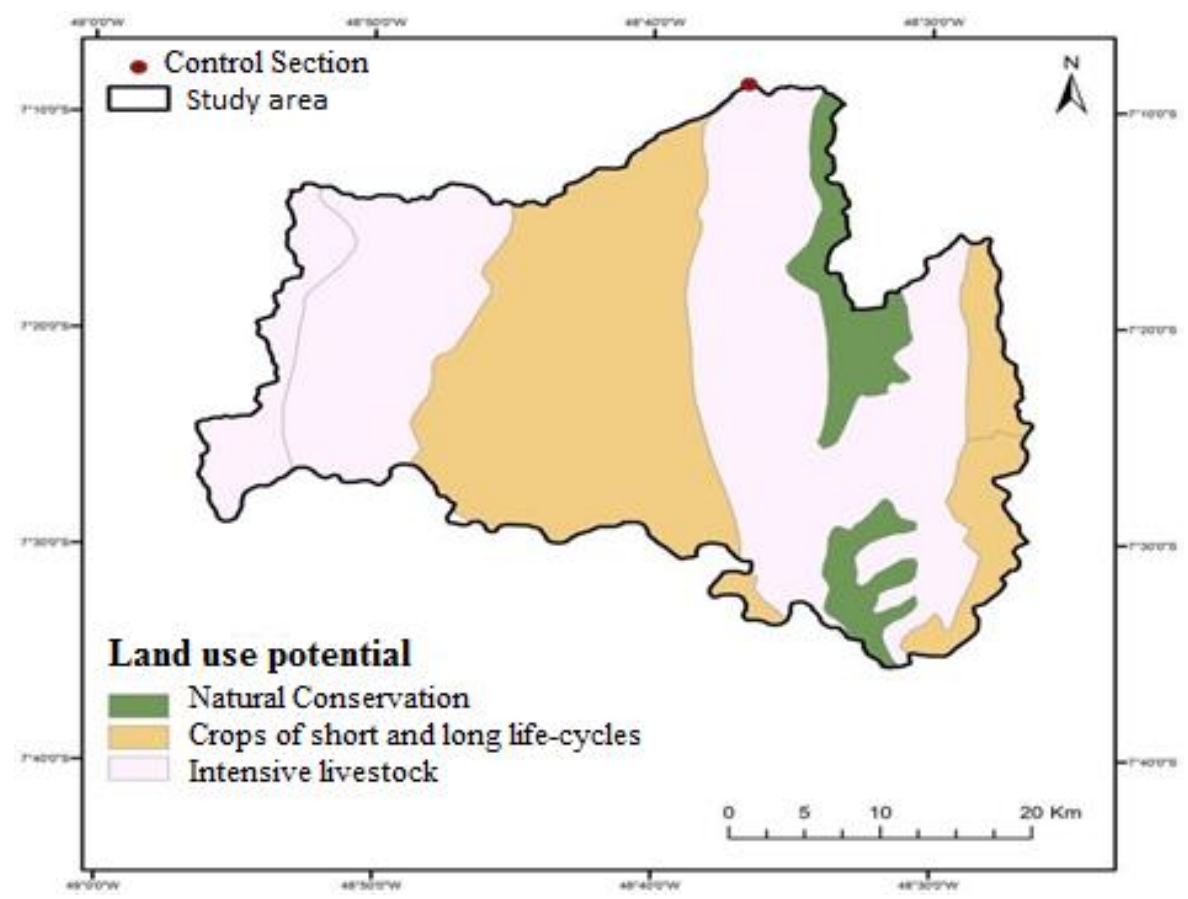

Figure 4. Land use potential of Muricizal sub-basin. Source: (Adapted from Tocantins, 2012.)

In regards to relief, it is possible to find diversity of forms within Muricizal river basin, especially those with a complex and diversified geomorphological process. Based on the use of digital data from orbital images organized by the SIG, it is possible to identify that the basin's altimetry has a higher predominance of flat to smooth relief, varying from flat to mountainous. The lowest point of the basin is quoted at 160 meters of ellipsoidal altitude and the peak at 618 meters, favouring its agricultural use. However, to the east, the basin has the largest portion of strong wavy to mountainous relief formation (Figure 6).

Aquino et al. (2009) consider that the course of Araguaia river can be divided into three sections: Upper Araguaia, Middle Araguaia and Lower Araguaia. The lower Araguaia, in particular, is located downstream of Conceição do Araguaia city, prevailing for $450 \mathrm{~km}$ until its confluence with Tocantins river at the border with the states of Pará,
Maranhão and Tocantins. The main tributaries of this stretch are by the right bank of the rivers: Jenipapo, Muricizal, Lontra, Corda, Piranhas II, Martinho and Barreiro and by the left margin, the rivers: Pau'darco, Itaipava, Xambioá and Gameleira outcropping of Paleozoic and Mesozoic rocks of Parnaíba Geological Province; although not really dominant, which explains the diversity of relief formation. Alves et al. (2009) point out that the relief forms of a given region always reflect on the use humans imprint to the landscape which can change considerably the use of soil and occupation.

The natural phytophysiognomy of Muricizal river hydrographic basin area is predominantly formed by Open Ombrophilous Forest 88,391 ha (56.4\%), Ombrophilous Forest / Deciduous Seasonal Forest 32,135 ha (20.5\%) and Savannah / Semideciduous Seasonal Forest 18,927 ha (12.1\%) (Figure 7). 


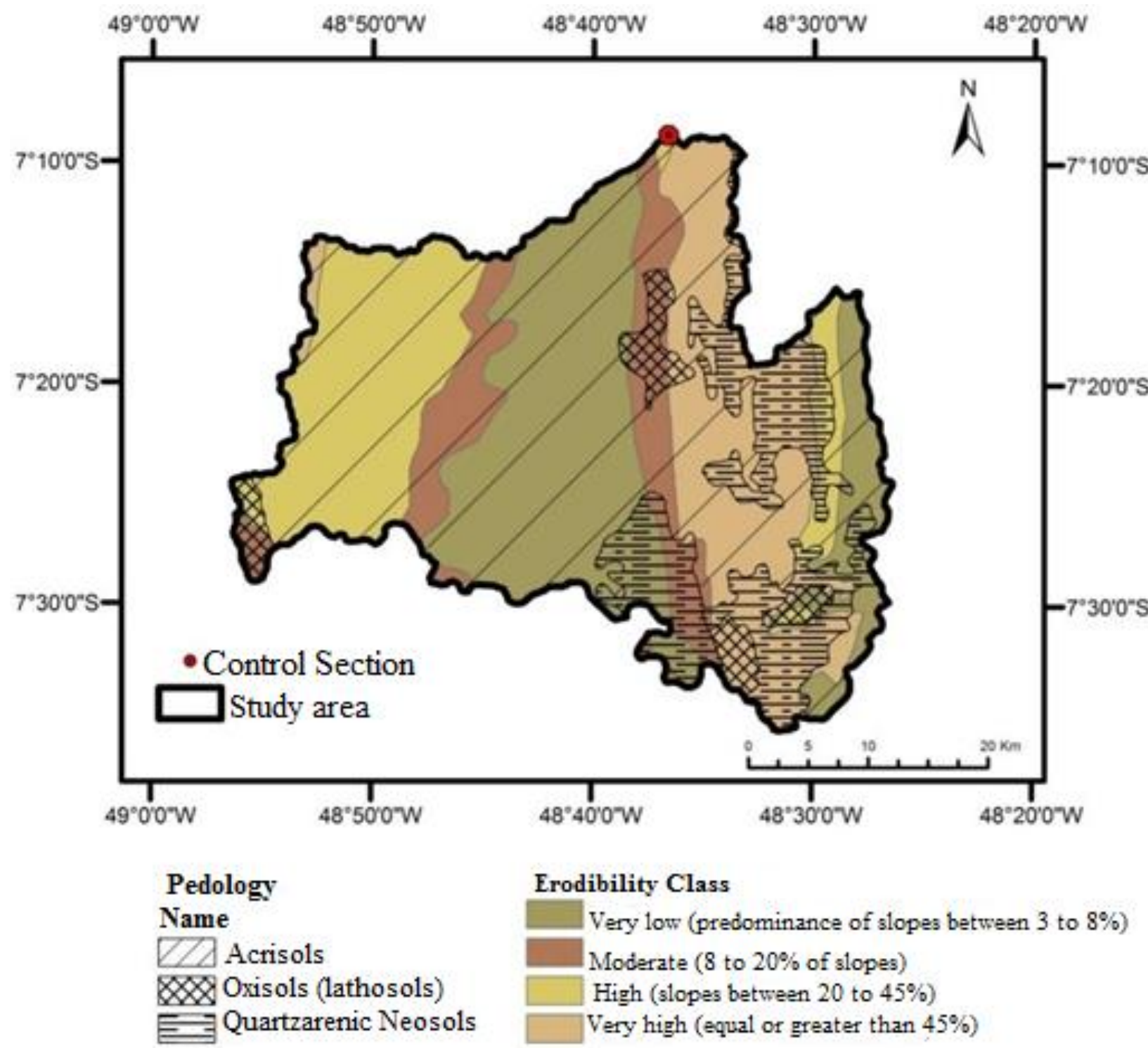

Figure 5. Pedology of the Muricizal sub-basin. Source: (adapted from Tocantins, 2012)

Viola et al. (2014) point out that Tocantins State is located in a geographical transition zone between the Cerrado (savannah) and the Amazon Forest, comprising the Midwest region of the State, yet it presents higher annual volumes in the vicinity of Cantão State Park. It is important to mention that climatic factors contribute directly to the Muricizal river basin to have phytophysiognomy diversification of landscapes, along with the presence of Cerrado and the Amazon rainforest.

Due to the higher occurrence of solar radiation registered between the months of May and August (Figure 8), the maximum temperature values follow similar patterns due to the high daytime temperatures (Figure 9). Similarly, the low relative humidity rates during this period (Figure 8) contribute to lower temperature values at night time (Figure 9).

The soil and atmosphere warming during periods of greatest solar radiation contribute to a significant drop in relative humidity, in which the lowest values occur in July, a condition perceived under the focus of an inverse relationship. In this chain, evapotranspiration presented a curve which was similar to that of solar radiation, thus having a direct positive relationship. 


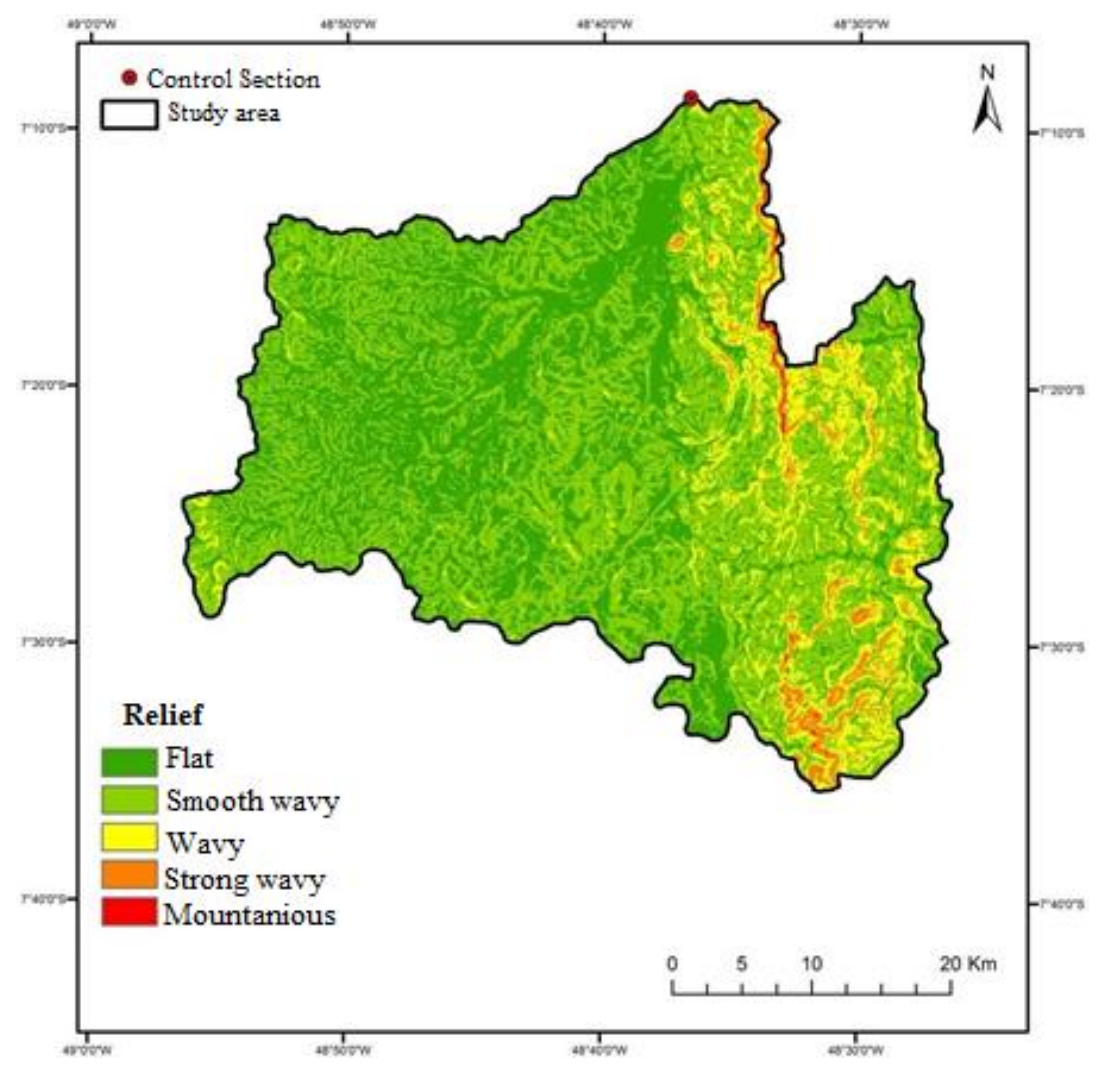

Figure 6. Relief of Muricizal sub-basin. Source: (adapted from Tocantins, 2012)

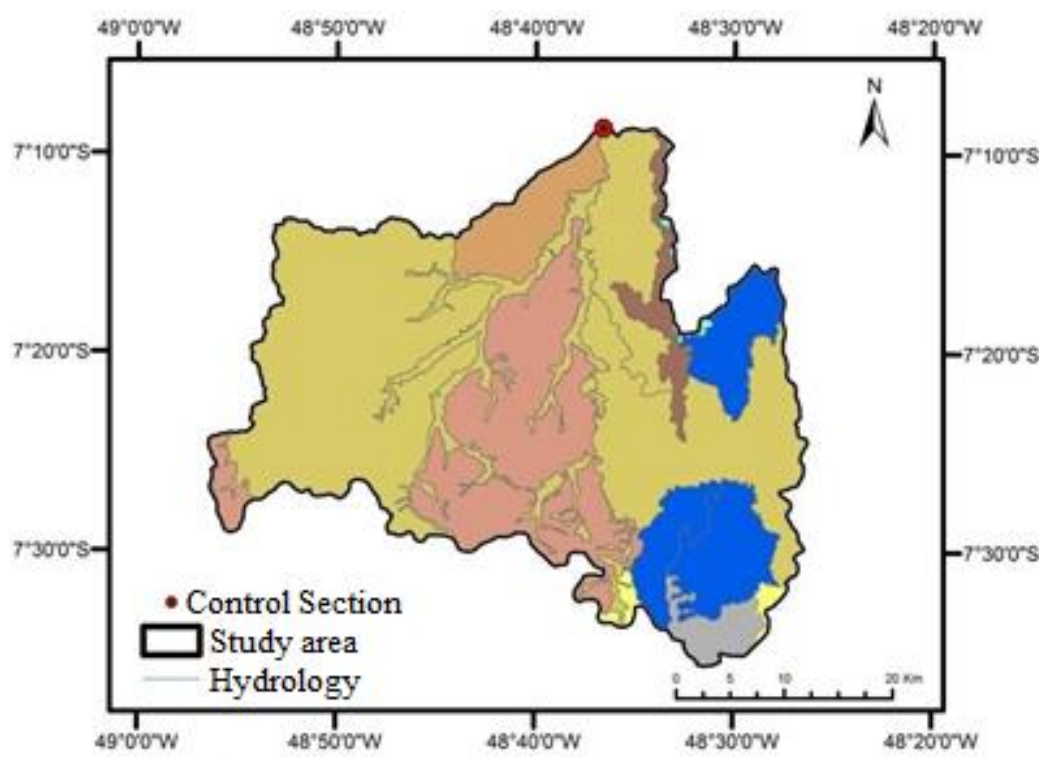

\section{Vegetation}

Decidual Seasonal Forest

Semideciduos Seasonal Forest

Ombrophilous Forest / Decidual forest (Contact)

Ombrophilous Open Forest

Ombropilous Dense Forest

Savanna (Cerrado)

Savanna/Decidual forest (Encrave)

Savanna/Semideciduous forest (Encrave

Figure 7. Vegetation of the Muricizal sub-basin. Source: (Adapted from Tocantins, 2012). 


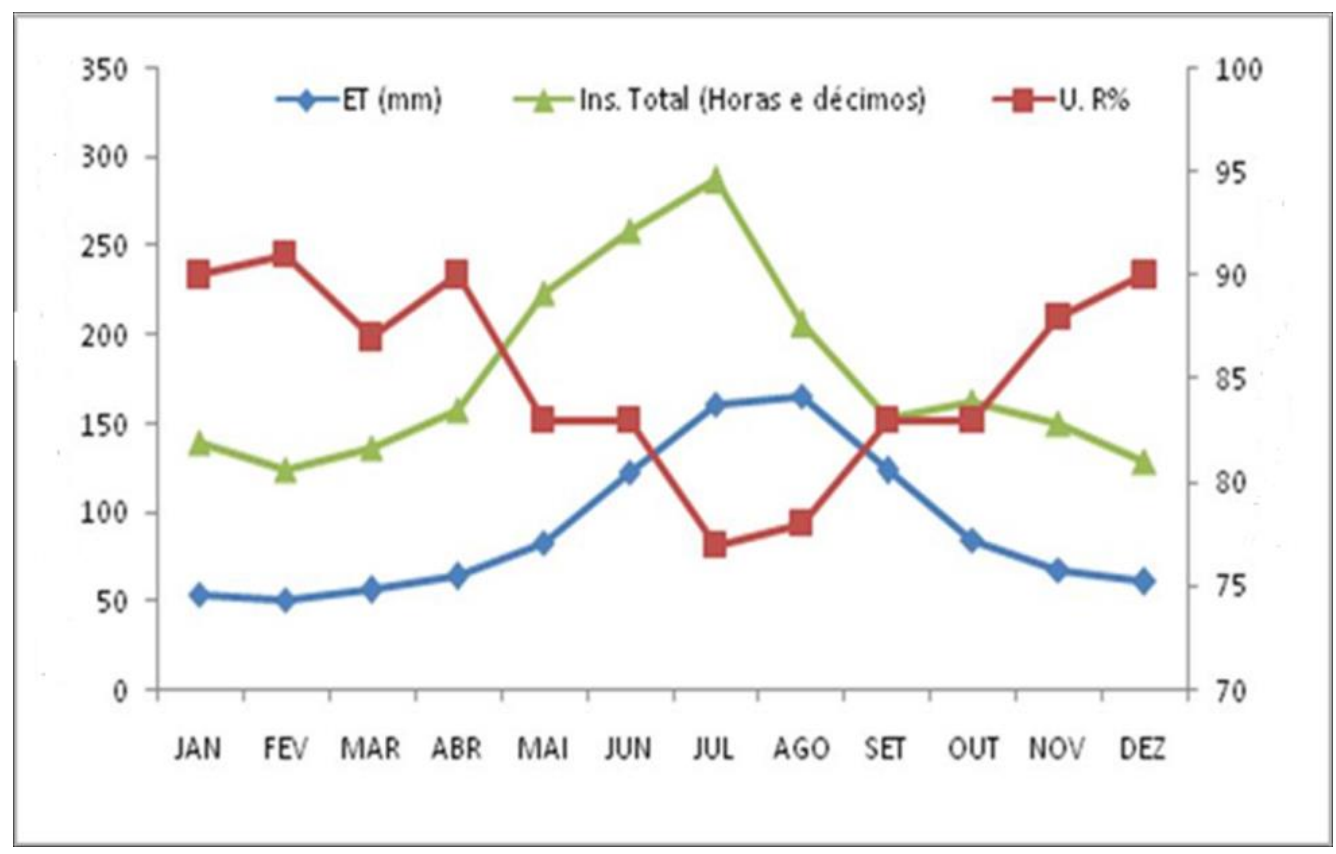

Figure 8. Evapotranspiration, relative humidity and insolation of the Muricizal sub-basin. Source: (adapted from ANA, 2018).

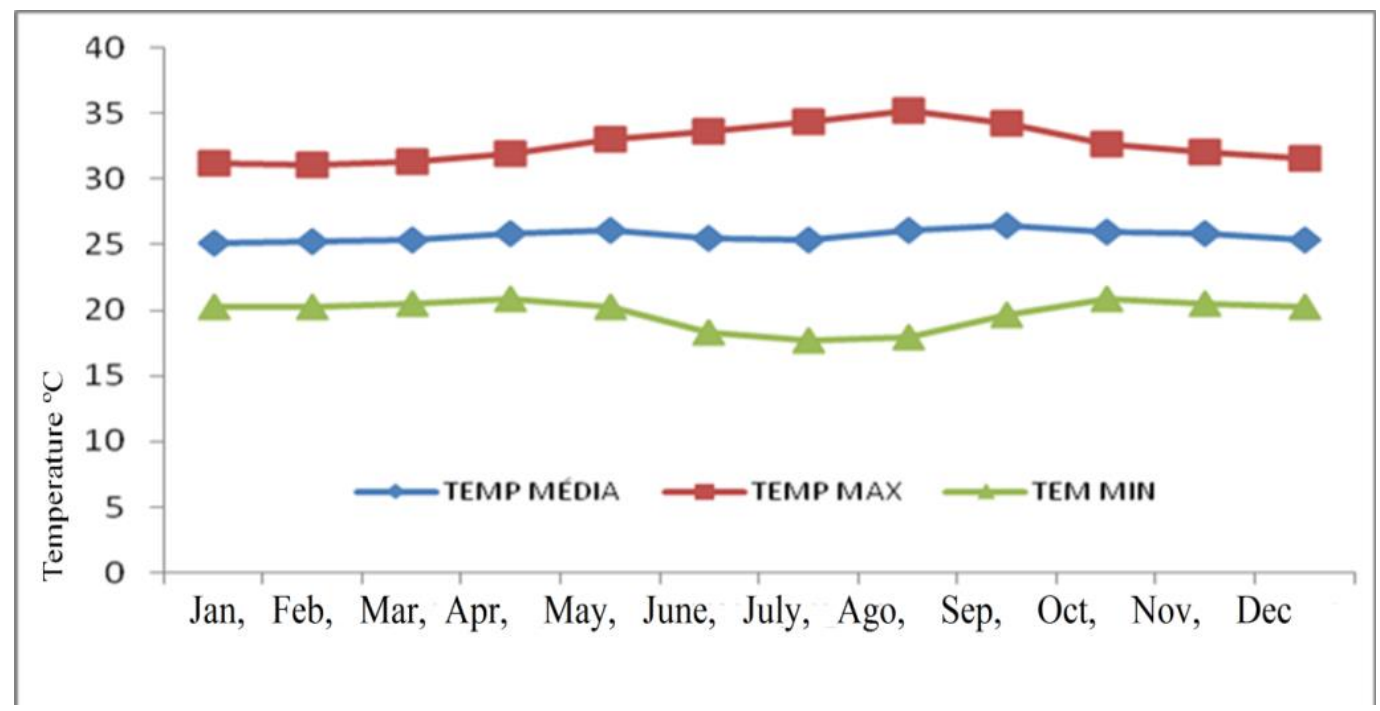

Figure 9. Maximum, minimum and average temperatures of the Muricizal sub-basin. Source: (Adapted from ANA, 2018.

\section{CONCLUSION}

The study on Muricizal river basin concluded how important it is to understand water dynamics in hydro-resource planning. The temporal series of rainfall data by historical season showed that it is possible to obtain information on rainfall throughout the year. This favours an understanding of the hydrological parameters of the studied area, the morphometric characterization subsidies in favour of actions aimed at the future use of hydro-resources as well as the river basin planning and management processes.

It was observed, through the evaluation of soil use and occupation, that the main activities within the river basin are livestock and agriculture. The low land slope favors the 
economic expansion of these activities. It is noteworthy that the types of soils in this basin contributed to their occupation in the development of the region over time, which possibly caused deforestation along the tributary margins and the River Muricizal.

\section{REFERENCES}

Agência Nacional de Águas - ANA (2018). Sistema de informações hidrológicasHidroWeb. Disponível em: http://hidroweb.ana.gov.br. Acesso em: 20 abri. 2018.

Alvarenga, C.C.; Mello, C.R.; Mello, J.M. \& Viola, M.R. (2011). Continuidade espacial da condutividade hidráulica saturada do solo na bacia hidrográfica do Alto Rio Grande, MG. R. Brasileitra de Ciência do Solo 35(5): 1745-1758. http://dx.doi.org/10.1590/S0100$\underline{06832011000500029 .}$.

Alves, R.R.; Serato, D.; Campos, E.H.U.; Campos, P.B.R.; Rodrigues, S.C.U. (2009). As relações existentes entre a ocorrência das formas do relevo e o uso do solo na bacia do Rio GrandeBA. (2009). XIII Simpósio Brasileiro de Geografia Física Aplicada. Viçosa: SBGF, UFV. Disponível em: http://www.geomorfologia.ufv.br/simposio/simpos io/trabalhos/trabalhos_completos/eixo4/020.pdf.

Acesso em: 20 abri. 2018.

Aquino, S.; Latrubesse, E.M. \& Souza Filho, E.E. (2009). Caracterização hidrológica e geomorfológica dos afluentes da Bacia do Rio Araguaia. Revista Brasileira de Geomorfologia 10(1): 43-54. http://dx.doi.org/10.20502/rbg.v10i1.116.

Cardoso, C.A.; Dias, H.C.T.; Soares, C.P.B. \& Martins, S.V. (2006). Caracterização morfométrica da bacia hidrográfica do rio Debossan, Nova Friburgo, RJ. Revista Árvore. 30(2):241-248. http://dx.doi.org/10.1590/S0100$\underline{67622006000200011 .}$.
Demarchi, J.C.; Zimback, C.R.L. (2014). Mapeamento, erodibilidade e tolerância de perdas de solo na sub - bacia do Ribeirão das Perobas. Energia na Agricultura 29(2):102-114. https://doi.org/10.17224/EnergAgric.2018v33n4.

Embrapa Solos. Sistema Brasileiro de Classificação de Solos. Brasilia-DF, 2013, 3 ed. $353 p$.

IBGE (2018) - Instituto Brasileiro de Geografia e Estatística. Brasil/Tocantins. 2018. Disponível em: https://cidades.ibge.gov.br/brasil/to/panorama. Acesso em: jul. de 2018.

Lepsch, I.F.; Bellinazzi, J.R.; Bertolini, D. \& Espíndola, C.R. (1991) Manual para levantamento utilitário do meio físico e classificação de terras no sistema de capacidade de uso. Campinas: Sociedade Brasileira de Ciência do Solo, 175p.

Lollo, J. A. (1995) O uso da técnica de avaliação do terreno no processo de elaboração do mapeamento geotécnico: sistematização e aplicação na quadrícula de Campinas: Escola de Engenharia de São Carlos, Universidade de São Paulo, São Carlos. Tese de Doutorado.

Marciano, A.G., Barbosa, A.A. \& Silva, A.P.M. (2018). Calculation of medium precipitation using the Thiessen method and the ridge. Revista Ambiente \& Água 13(1): 01-17. https://doi:10.4136/ambi-agua.1906.

Marcuzzo, F.F.N., \& Goularte, E.R.P. (2012). Índice de anomalias de chuvas do estado do Tocantins. Geoambiente 19: 01-17. https://doi.org/10.5216/revgeoamb.v0i19.26056

Mello, C. R.; Viola, M.R.; Curi, N. \& Silva, A.M. (2012). Distribution of monthly and annual rainfall and rainfall erosivity in Espirito Santo, Brazil. Revista Brasileira de Ciência do Solo 36(6):1878-1891.

http://dx.doi.org/10.1590/S0100-

$\underline{06832012000600022}$.

Merten, G.H.; Minella, J.P.G.; Reichert, J.M. \& Moro, M. (2011). Implicações do uso e manejo do solo e das variações climáticas sobre os recursos 
hídricos. Tópicos em Ciência do Solo 7: 307-366

Oliveira, J.A. (2014). A influência do relevo como fator de formação de solos:uma analise na área da Embrapa, Sete Lagoas MG. Revista Geonorte 5(21):1-4.

Panachuki, E.; Alves Sobrinho, T.; Vitorino, A.C.T.; Carvalho, D.F. \& Urchei, M.A. (2006). Parâmetros físicos do solo e erosão hídrica sob chuva simulada, em áreas de integração agrícola pecuária. Revista Brasileira de Engenharia Agrícola e Ambiental 10(2):261-268.

Pinheiro, R.T.; \& Dornas, T. (2009). Bird distribution and conservation on Cantão region, State of Tocatins: Amazon/Cerrado ecotone. Biota Neotropica 9(1):187-205. http://dx.doi.org/10.1590/S1676$\underline{06032009000100019}$.

Rampim, L.; Tavares Filho, J.; Behlau, F. \& Romano, D. (2012). Determinação da capacidade de uso do solo visando o manejo sustentável para uma média propriedade em LondrinaPR. Bioscience Journal 28(2):251-264.

Rodrigues, A.S.L.; Castro, P.T.A. \& Malafaia, G. (2010). Utilização dos protocolos de avaliação rápida de rios como instrumentos complementares na gestão de bacias hidrográficas envolvendo aspectos da geomorfologia fluvial: uma breve discussão. Enciclopédia Biosfera 6(11):1-9.

Santos, D.M.; Araújo, S.M.; Araujo, K.D.; Rosa, P.R.O. \& Pazera JR, E. (2009). Variabilidade temporal da radiação solar e Insolação no município de Araguaína - TO. RAEGA 6:35-40. http://dx.doi.org/10.5380/raega.v18i0.14965.

Sari, V.; Paiva, E.M.C.D.; \& Paiva, J.B.D. (2016) Rainfall interception in different forest formations in the southern region of Brazil. RBRH 21(1): 6579. http://dx.doi.org/10.21168/rbrh.v21n1.

Silva, R. F.; Santos, V.A. \& Sanndy, M.G.G. (2016). Análise dos impactos ambientais da Urbanização sobre os recursos hídricos na subbacia do Córrego Vargem Grande em Montes Claros-MG. Caderno de Geografia 26(47): 966-
976. 2962.2016v26n47p966.

https://doi.org/10.5752/P.2318-

Tocantins. (2012). Atlas do Tocantins: subsídios ao planejamento da gestão territorial. Palmas: Seplan.Vol. 6. SEPLAN. p. 9-79. Disponível em:http://www.seplan.to.gov.br/Portal/acontece/at las2012. Acesso em: 07 Jun. 2018.

Tomazoni, J.C.; Guimarães, E.; Gomes, T.C. \& Silva, T.G. (2011). Uso de Modelo Digital de Elevação Gerados a partir do ASTER GDEM e SRTM para Caracterização da Rede de Drenagem do Município de Renascença no Sudoeste do Estado do Paraná. Revista Brasileira de Geografia Física 4(2):365-376.

Tundisi, J.G (2013). Governança da água. Revista da Universidade Federal de Minas Gerais 20(2):222-335.

Vanzela, L.S; Hernandez, F.B.T. \& Franco, R.A.M. (2010). Influência do uso e ocupação do solo nos recursos hídricos do Córrego Três Barras, Marianôpolis. Revista Brasileira de Engenharia Agricola e Ambiental-Agriambi 14(1):55-64. http://dx.doi.org/10.1590/S1415$\underline{43662010000100008 .}$.

Villela, S. M. \& Mattos, A. Hidrologia aplicada. São Paulo: Mc Graw Hill, 1975. 245 p.

Viola, M. R.; Avanzi, J.C.; Mello, C.R.; Lima, S.O. \& Alves, M.V.G. (2014). Distribuição e potencial erosivo das chuvas no Estado do Tocantins. Pesquisa Agropecuária Brasileira 49(2):125-135. http://DOI: 10.1590/S0100204X2014000200007.

Viola, M.R.; Mello, C.R.; Acerbi Jr, F.W.; Silva, A.M. (2009). Modelagem hidrológica na bacia hidrográfica do Rio Aiuruoca, MG. Revista Brasileira de Engenharia Agrícola e Ambiental 13(5):581-590. 